\title{
Aging and Repetition Errors: Can the Automatic Influence of Familiarity be Controlled?
}

\section{A. Charles and F. Knap}

\section{(2) OpenEdition \\ 12 Journals}

\section{Electronic version}

URL: http://journals.openedition.org/cpl/148

DOI: $10.4000 / \mathrm{cpl} .148$

ISSN: $1379-6100$

\section{Publisher}

Centre PsyCLÉ

Printed version

Date of publication: 1 April 2002

\section{Electronic reference}

A. Charles and F. Knap, « Aging and Repetition Errors: Can the Automatic Influence of Familiarity be Controlled ? ", Current psychology letters [Online], 2002/1, 7 | 2002, Online since 04 September 2003, connection on 08 September 2020. URL : http://journals.openedition.org/cpl/148 ; DOI : https:// doi.org/10.4000/cpl.148

This text was automatically generated on 8 September 2020.

(C) All rights reserved 


\section{Aging and Repetition Errors: Can the Automatic Influence of Familiarity be Controlled?}

A. Charles and F. Knap 